\title{
Role of urotensin II in advanced glycation end product-induced extracellular matrix synthesis in rat proximal tubular epithelial cells
}

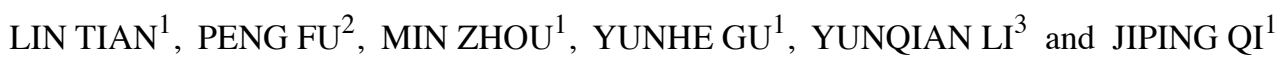 \\ Departments of ${ }^{1}$ Pathology, and ${ }^{2}$ Nuclear Medicine, The First Affiliated Hospital of Harbin Medical University, Harbin, \\ Heilongjiang 150001; ${ }^{3}$ Department of Neurosurgery, The First Hospital, Jilin University, Changchun, Jilin 130021, P.R. China
}

Received October 30, 2015; Accepted October 17, 2016

DOI: $10.3892 /$ ijmm.2016.2789

\begin{abstract}
Urotensin II (UII) was first recognized for its constrictive and natriuretic properties in fish almost 40 years ago, and recent studies have suggested that it exerts pro-fibrotic effects in a number of cell lines. In this study, we aimed to evaluate the role of UII in extracellular matrix (ECM) synthesis and secretion in advanced glycation end product (AGE)-stimulated rat proximal tubular epithelial cells (NRK-52E cells). UII promoted the proliferation of the NRK-52E cells in a dose-dependent manner over a concentration range of $10^{-10}-10^{-8} \mathrm{~mol} / \mathrm{l}$ and this effect was partly inhibited by both nimodipine and EDTA. Furthermore, AGE-BSA promoted the mRNA and protein expression of UII, fibronectin (FN) and collagen IV (ColIV) in the NRK-52E cells in a dose- and time-dependent manner. In addition, UII promoted the mRNA expression and protein secretion of transforming growth factor (TGF)- $\beta 1, \mathrm{FN}$ and $\mathrm{Col}$ IV by the NRK-52E cells. Our results suggest that UII promotes the proliferation of NRK-52E cells, an effect which is mediated by the influx of extracellular calcium ions. In addition, our data indicate that AGEs promote UII expression in NRK-52E cells, and that TGF- $\beta 1$ signaling is a candidate pathway mediating the involvement of UII in renal fibrosis. Collectively, our data suggest that the UII-TGF- $\beta 1$ signaling may be an important factor in tubulointerstitial nephropathy in diabetes.
\end{abstract}

\section{Introduction}

Urotensin II (UII), the most potent vasoconstrictor known, was first recognized for its constrictive and natriuretic properties

Correspondence to: Dr Jiping Qi, Department of Pathology, The First Affiliated Hospital of Harbin Medical University, Harbin, Heilongjiang 150001, P.R. China

E-mail: bless88775469@163.com

Dr Yunqian Li, Department of Neurosurgery, The First Hospital, Jilin University, Changchun, Jilin 130021, P.R. China

E-mail: yunqianli@gmail.com

Key words: urotensin II, transforming growth factor, advanced glycation end products, diabetes in fish almost 40 years ago. The UII peptide was subsequently isolated from frog brain and, later, the prepro-UII cDNA was characterized in various mammals, including humans. In the central nervous system (CNS) of tetrapods, UII is expressed primarily in the motor neurons of the brainstem and spinal cord. The biological functions of UII are mediated through a $\mathrm{G}$ protein-coupled receptor, termed UT, that exhibits high sequence similarity with the somatostatin receptors. The UT gene is widely expressed in the CNS and in peripheral organs. Consistent with their broad distribution, UT and UII exert a broad range of behavioral effects and regulate endocrine, cardiovascular, kidney and immune functions $(1,2)$.

Diabetic nephropathy (DN) is a severe microvascular complication commonly observed in patients with diabetes, and is also the leading cause of end-stage renal disease (ESRD). Tubulointerstitial nephropathy is closely associated with the impairment of renal function in the pathogenesis of diabetic nephropathy. Advanced glycation end products (AGEs) are formed by the Maillard process, a non-enzymatic reaction between ketones or aldehydes and the amino groups of proteins, lipids and nucleic acids, and are known to contribute to the aging of macromolecules. Under conditions of hyperglycemia and/or oxidative stress, this process begins with the conversion of reversible Schiff base adducts to more stable, covalently-bound Amadori rearrangement products. AGEs play important roles in the pathogenesis of diabetic nephropathy by upregulating the expression of cytokines in tubular epithelial cells and stimulating the accumulation of extracellular matrix $(\operatorname{ECM})(3,4)$. UII is a potent vasoconstrictor peptide, which promotes proliferation and ECM synthesis, in both an autocrine and paracrine manner in renal epithelial cells $(5,6)$. Elevated UII levels have been detected in the plasma of patients with diabetes (7). In addition, the UII and UT genes have been shown to be upregulated in both the aorta and kidneys of non-obese diabetic rats (8). Peaks in the renal expression levels of UII and UT have been observed in epithelial cells of the distal tubule, the proximal tubule and collecting tubule epithelial cells (9), suggesting that UII may be involved in the etiology of DN.

Transforming growth factor $\beta 1$ (TGF- $\beta 1$ ) is expressed primarily in the kidneys and has been shown to promote renal fibrosis $(10,11)$. Dai et al (12) found that TGF- $\beta 1$ modulated the pro-fibrogenic effects of UII in neonatal cardiac fibroblasts 
via UT. However, the specific mechanisms through which UII promotes the synthesis of ECM by tubular epithelial cells remain unknown. This study aimed to determine the fibrotic effects of UII in cultured rat proximal renal tubular epithelial cells (NRK-52E cells) in the presence of AGEs, and to identify the signaling pathways involved in these effects.

\section{Materials and methods}

Preparation of AGE-bovine serum albumin (BSA). Briefly, BSA and glucose were dissolved in phosphate-buffered saline (PBS) at final concentrations of $0.5 \mathrm{~mol} / \mathrm{l}$ of glucose and $10 \mathrm{mg} / \mathrm{ml}$ of BSA. The solution was sterilized by ultrafiltration, incubated at $37^{\circ} \mathrm{C}$ for 90 days, and finally dialyzed against PBS to remove free glucose. As a control, BSA was incubated in parallel without D-glucose. No endotoxin was detectable in these preparations. The levels of AGE-BSA and BSA were 15.1 and 4.3 arbitrary units detected by spectrofluorimetry [using a fluorescence photometer (INFINITE 200 PRO; Tecan Austria GmbH, Grödig, Austria)] with an excitation wavelength of $370 \mathrm{~nm}$, an emission wavelength of $440 \mathrm{~nm}$, and a split of $3 \mathrm{~nm}$.

Cell culture and experimental design. Rat proximal tubular epithelial cells (NRK-52E cells) were purchased from the Stem Cell Bank, Chinese Academy of Sciences, Shanghai, China. The cells were resuspended in Dulbecco's modified Eagle's medium (DMEM) (Sigma-Aldrich, St. Louis, MO, USA) supplemented with 20\% FBS and $100 \mathrm{IU} / \mathrm{ml}$ antibiotics. A suspension of NRK-52E cells was plated into tissue culture flasks and incubated at $37^{\circ} \mathrm{C}$ in $5 \% \mathrm{CO}_{2}$.

Effects of UII on the proliferation of NRK-52E cells. The cells were cultured for $48 \mathrm{~h}$ with various concentrations $\left(10^{-10}, 10^{-9}\right.$, $10^{-8}$ and $10^{-7} \mathrm{~mol} / \mathrm{l}$ ) of UII (Sigma-Aldrich). Nimodipine (Bayer, Leverkusen, Germany)-pre-treated cells were incubated with $10^{-5} \mathrm{~mol} / \mathrm{l}$ nimodipine for $5 \mathrm{~min}$ and then cultured with $10^{-8} \mathrm{~mol} / \mathrm{l}$ UII for $48 \mathrm{~h}$. The EDTA-treated cells were pre-treated with EDTA for $30 \mathrm{~min}$ and then cultured with $10^{-8} \mathrm{~mol} / \mathrm{l} \mathrm{UII} \mathrm{for} 48 \mathrm{~h}$. For the final $2 \mathrm{~h}$ of the culture period, $10^{-4} \mathrm{~mol} / 1$ 5-bromodeoxyuridine (BrdU; Sigma-Aldrich) were added before the cells and the supernatant were collected. The cells in the control group were cultured for $48 \mathrm{~h}$ without being subjected to any treatment.

Effects of AGEs on the protein expression of UII in NRK-52E cells. The cells were cultured with AGE-BSA $(100 \mathrm{mg} / \mathrm{l})$ or BSA (control) and serum- free DMEM (blank control) for $48 \mathrm{~h}$ and then collected for western blot analysis.

Effects of AGEs on the UII mRNA expression and protein secretion of fibronectin $(F N)$ and collagen (Col)IV in NRK-52E cells. To examine the effects of AGE-BSA at various concentrations, the cells were cultured with $0,25,50,100$ and $200 \mathrm{mg} / 1$ AGE-BSA or BSA (control). The cells and supernatants were collected at $48 \mathrm{~h}$ post-treatment. In a separate time-course experiment, the cells were cultured with AGE-BSA at $100 \mathrm{mg} / \mathrm{l}$ or BSA (control). The cells and supernatant were collected at 0 , $2,8,16,24$ or $48 \mathrm{~h}$ post-treatment.

Effects of UII on the expression of TGF- $\beta 1, F N$, and ColIV in $N R K-52 E$ cells. The cells were cultured with $10^{-8} \mathrm{~mol} / \mathrm{l}$ UII for
$48 \mathrm{~h}$. The urantide-pre-treated cells were pre-treated with urantide $\left(10^{-6} \mathrm{~mol} / \mathrm{l}\right.$; Shanghai Huada Tianyuan Biology Co., Ltd., Shanghai, China) for $30 \mathrm{~min}$ and then cultured with $10^{-8} \mathrm{~mol} / 1$ UII for $48 \mathrm{~h}$. The anti-TGF- $\beta 1$ antibody-pre-treated cells were pre-treated with anti-TGF- $\beta 1$ antibody $(10 \mu \mathrm{g} / \mathrm{ml}$; monoclonal nouse; Cat no. MAB240, R\&D Systems Inc., Minneapolis, MN, USA) for $30 \mathrm{~min}$ and then cultured with $10^{-8} \mathrm{~mol} / 1$ UII for $48 \mathrm{~h}$. The cells and culture supernatants were collected. The cells in the control group were cultured for $48 \mathrm{~h}$ without any special treatment.

Flow cytometry. The cells were released with $0.25 \%$ trypsin, washed with PBS and fixed in $70 \%$ ethanol at $4^{\circ} \mathrm{C}$ overnight.The cells were collected by centrifugation $(1000 \mathrm{x} \mathrm{g})$ and washed with PBS. The cells were resuspended in PBS. The cell concentration was adjusted to $1.0 \times 10^{6}$ and RNaseA was added, at $37^{\circ} \mathrm{C}$ in a water bath for $30 \mathrm{~min}$ and then stained with propidium iodide at $4^{\circ} \mathrm{C}$ for $30 \mathrm{~min}$ in the dark. The distribution of the cells was analyzed using Modfit LT 3.0 software (BD FACSCanto II Flow Cytometer, BD Biosciences, San Jose, CA, USA).

Enzyme-linked immunosorbent assay (ELISA). The medium was collected from the cultured NRK-52E cells with or without the treatments described above and centrifuged $\left(1000 \times \mathrm{g}, 4^{\circ} \mathrm{C}\right)$ immediately. The supernatant was then assayed using a BrdU ELISA kit (Sigma-Aldrich) or ELISA kits for FN and ColIV (R\&D Systems Inc.) according to the manufacturer's instructions. The absorbance of the colored products was determined using a microplate reader (VERSA max, sn: BNR05706; Molecular Devices, Sunnyvale, CA, USA) set to $490 \mathrm{~nm}$.

$R T-P C R$. Total RNA was extracted from the cultured NRK-52E cells using TRIzol reagent (Gibco Life Technologies, Carlsbad, CA, USA). Primers for UII, TGF- $\beta 1$, FN, ColIV and glyceraldehyde-3-phosphate dehydrogenase (GAPDH) were designed and synthesized by Shanghai Biological Engineering (Shanghai, China). The sequences of these primers are presented in Table I.

Total RNA $(0.5 \mu \mathrm{g})$ was amplified using the Titan ${ }^{\mathrm{TM}}$ One Tube RT-PCR kit (Boehringer-Mannheim, Shanghai, China). Twenty-five cycles of replication were used. The products were separated by agarose gel electrophoresis and visualized by ethidium bromide staining. Bands were digitized using a Tanon-1000 gel image system (Shanghai, China). The ratios of UII, TGF- $\beta 1, F N$ and ColIV band density to GAPDH band density in the various groups are presented.

Western blot analysis. The protein level of UII was analyzed by western blot analysis. Equal amounts of lysates were separated by sodium dodecyl sulfate-polyacrylamide gel electrophoresis (SDS-PAGE) and transferred onto Bio-Rad Trans-Blot nitrocellulose membranes (Bio-Rad Laboratories, Inc., Hercules, CA, USA). The membranes were incubated in blocking buffer (Tris-buffered saline containing $0.1 \%$ polysorbate 20 and $5 \%$ non-fat dried milk) for $1 \mathrm{~h}$ at room temperature followed by incubation with the appropriate primary antibody (anti-UII; 1:1,000 dilution; polyclonal goat, Cat. no. sc-21096; Santa Cruz Biotechnology, Inc.; Santa Cruz, CA, USA) overnight at $4^{\circ} \mathrm{C}$ with gentle shaking. The membranes were washed 3 times ( 15 min each) with washing buffer (Tris-buffered saline containing $0.1 \%$ polysorbate 20 ) 
Table I. Upstream and downstream primers for UII, TGF- $\beta 1, \mathrm{FN}, \mathrm{Col}$ IV and GAPDH.

\begin{tabular}{llc}
\hline Primer & \multicolumn{1}{c}{ Sequence } & Length (bp) \\
\hline UII sense & 5'-TGCCTGCTCTTCGTAGGACT-3' & 242 \\
UII antisense & 5'-AGAGCCTTCCTCAAGCTT-3' \\
TGF- $\beta 1$ sense & 5'-CCAAGGAGACGGAATACAGG-3' \\
TGF- $\beta 1$ antisense & 5'-GTGTTGGTTGTAGAGGGCAAG-3' \\
FN sense & 5'-CCTTTCTGAGCAGCAACC-3' \\
FN antisense & 5'-AAGGACCACAGGAGCAGT-3' \\
Col IV sense & 5'-CTTCGCCTCCAGGAACGA-3' \\
Col IV antisense & 5'-TGGGCTTCTTGAACATCTCG-3' \\
GAPDH sense & 5'-ACCACAGTCCATGCCATCAC-3' \\
GAPDH antisense & 5'-TCCACCACCCTGTTGCTGTA-3' \\
\hline
\end{tabular}

UII, urotensin II; TGF- $\beta 1$, transforming growth factor- $\beta 1$; FN, fibronectin; Col IV, collagen IV; GAPDH, glyceraldehyde-3-phosphate dehydrogenase.

Table II. Effects of UII at various concentrations on the proliferation of NRK-52E cells.

\begin{tabular}{llllll}
\hline Group & $\mathrm{n}$ & Value of A & G1 Phase $(\%)$ & S Phase $(\%)$ & G2 Phase $(\%)$ \\
\hline Control & 6 & $0.556 \pm 0.039$ & $56.46 \pm 2.88$ & $20.46 \pm 4.44$ & $23.56 \pm 3.75$ \\
$10^{-10} \mathrm{~mol} / 1$ & 6 & $0.491 \pm 0.038^{\mathrm{a}}$ & $49.63 \pm 3.06$ & $26.96 \pm 3.35^{\mathrm{a}}$ & $22.75 \pm 3.36$ \\
$10^{-9} \mathrm{~mol} / \mathrm{l}$ & 6 & $0.281 \pm 0.037^{\mathrm{a}}$ & $37.48 \pm 2.06$ & $44.26 \pm 3.28^{\mathrm{a}}$ & $18.12 \pm 1.82$ \\
$10^{-8} \mathrm{~mol} / \mathrm{l}$ & 6 & $0.291 \pm 0.023^{\mathrm{a}}$ & $34.03 \pm 1.92$ & $48.12 \pm 2.22^{\mathrm{a}}$ & $18.18 \pm 1.81$ \\
$10^{-7} \mathrm{~mol} / 1$ & 6 & $0.524 \pm 0.035$ & $63.33 \pm 2.46$ & $20.85 \pm 2.21$ & $16.81 \pm 2.46$ \\
\hline
\end{tabular}

The cells were cultured for $48 \mathrm{~h}$ with various concentrations of urotensin II (UII; $10^{-10}, 10^{-9}, 10^{-8}$, and $10^{-7} \mathrm{~mol} / 1$; Sigma-Aldrich). Subsequently, $10^{-4} \mathrm{~mol} / \mathrm{l} 5$-bromodeoxyuridine (BrdU) (Sigma-Aldrich) were added for the last $2 \mathrm{~h}$ before the cells and the supernatant were collected. Cells in the control group were cultured for $48 \mathrm{~h}$ without any treatment. Flow cytometry was used to examine the distribution of the cells and the results were analyzed using Modfit LT 3.0 software. ELISA was used to assay the BrdU content (value of A) in the culture supernatants. Data are the means $\pm \mathrm{SD}$. ${ }^{\mathrm{P}} \mathrm{P}<0.05$ vs. control group.

and incubated with goat anti-mouse secondary antibody (1:2,000 dilution; rabbit-anti-goat, Cat. no. sc-2031; Santa Cruz Biotechnology, Inc.) for $1 \mathrm{~h}$ at room temperature. After washing as described above, the protein of interest was detected using enhanced chemiluminescence reagents from Amresco (Solon, OH, USA). Protein expression levels are expressed as a ratio to GAPDH (polyclonal rabbit, Cat. no. 2118; Cell Signaling Technology, Danvers, MA, USA) levels. Protein bands were detected and analyzed with a gel imaging system.

Statistical analysis. All data were analyzed using the statistical software package SPSS 16.0 (SPSS Inc., Chicago, IL, USA) and are expressed as the means \pm standard deviation. Comparisons were performed using one-way and two-way ANOVA. A $\mathrm{P}$-value of $<0.05$ was considered to indicate a statistically significant difference.

\section{Results}

UII stimulates the proliferation of NRK-52E cells. The cell proliferation cycle includes 4 phases, the G1, S, G2 and $M$ phases; the $S$ phase is the DNA synthesis phase and increased cell proliferation was indicated by an increase in the number of cells in the $S$ phase. UII promoted the proliferation of the NRK-52E cells in a concentrationdependent manner following treatment at $10^{-10}$ to $10^{-8} \mathrm{~mol} / \mathrm{l}$. Unexpectedly, treatment with UII at $10^{-7} \mathrm{~mol} / 1$ failed to significantly increase cell proliferation relative to the controls (Table II and Fig. 1). The promoting effect of UII on cell proliferation was partially blocked by treatment with nimodipine and EDTA (Fig. 1 and Table III).

AGE-BSA upregulates the protein expression of UII in NRK-52E cells. The AGE-BSA-stimulated UII protein expression in NRK-52E cells was examined by western blot analysis. AGE-BSA upregulated UII protein expression in the NRK-52E cells compared with the blank control and BSA groups (Fig. 2).

AGE-BSA upregulates $m R N A$ expression of UII in NRK-52E cells. AGE-BSA upregulated UII mRNA expression in the NRK-52E cells in a concentration-dependent manner, and the NRK-52E cells treated with $100 \mathrm{mg} / \mathrm{l}$ AGE-BSA exhibited a time-dependent increase in UII mRNA expression between 2 and 48 h of treatment (Figs. 3 and 4).

AGE-BSA stimulates the secretion of FN and ColIV by $N R K-52 E$ cells. The concentrations of FN and ColIV in the supernatant of NRK-52E cells were increased following treat- 
Table III. Effects of nimodipine and EDTA on the proliferation of NRK-52E cells induced by UII.

\begin{tabular}{llllll}
\hline Group & $\mathrm{n}$ & Value of A & G1 Phase $(\%)$ & S Phase $(\%)$ & G2 Phase $(\%)$ \\
\hline Control & 6 & $0.556 \pm 0.039$ & $56.46 \pm 2.88$ & $20.46 \pm 4.44$ & $23.56 \pm 3.75$ \\
$10^{-8} \mathrm{~mol} / \mathrm{l}$ UII & 6 & $0.291 \pm 0.023^{\mathrm{a}}$ & $34.03 \pm 1.92$ & $48.12 \pm 2.22^{\mathrm{a}}$ & $18.18 \pm 1.81$ \\
$10^{-8} \mathrm{UII}+$ Nim & 6 & $0.466 \pm 0.037^{\mathrm{a}, \mathrm{b}}$ & $46.91 \pm 1.67$ & $34.45 \pm 2.83^{\mathrm{a}, \mathrm{b}}$ & $17.91 \pm 1.44$ \\
$10^{-8}$ UII + EDTA & 6 & $0.451 \pm 0.035^{\mathrm{a}, \mathrm{b}}$ & $47.51 \pm 1.22$ & $32.90 \pm 2.52^{\mathrm{a}, \mathrm{b}}$ & $19.40 \pm 2.15$ \\
\hline
\end{tabular}

The cells were cultured for $48 \mathrm{~h}$ with various concentrations of urotensin II (UII; $10^{-8} \mathrm{~mol} / \mathrm{l}$; Sigma-Aldrich). Nimodipine-pre-treated cells were incubated with $10^{-5} \mathrm{~mol} / \mathrm{l}$ nimodipine for $5 \mathrm{~min}$ and then cultured with $10^{-8} \mathrm{~mol} / \mathrm{l}$ UII for $48 \mathrm{~h}$. EDTA-treated cells were treated with EDTA for $30 \mathrm{~min}$ and then cultured with $10^{-8} \mathrm{~mol} / \mathrm{l}$ UII for $48 \mathrm{~h}$. Subsequently, $10^{-4} \mathrm{~mol} / \mathrm{l}$ 5-bromodeoxyuridine (BrdU) (Sigma-Aldrich) were added for the last $2 \mathrm{~h}$ before the cells and the supernatant were collected. Cells in the control group were cultured for $48 \mathrm{~h}$ without any treatment. Flow cytometry shows the distribution of the cells, analyzed using Modfit LT 3.0 software. ELISA detection of the content of BrdU (value of A) in the supernatant culture solution. Data are the means $\pm \mathrm{SD}$. ${ }^{\mathrm{P}}<0.05$ vs. control group; ${ }^{\mathrm{b}} \mathrm{P}<0.05 \mathrm{vs} .10^{-8} \mathrm{~mol} / 1$ UII group. Nim, nimodipine.

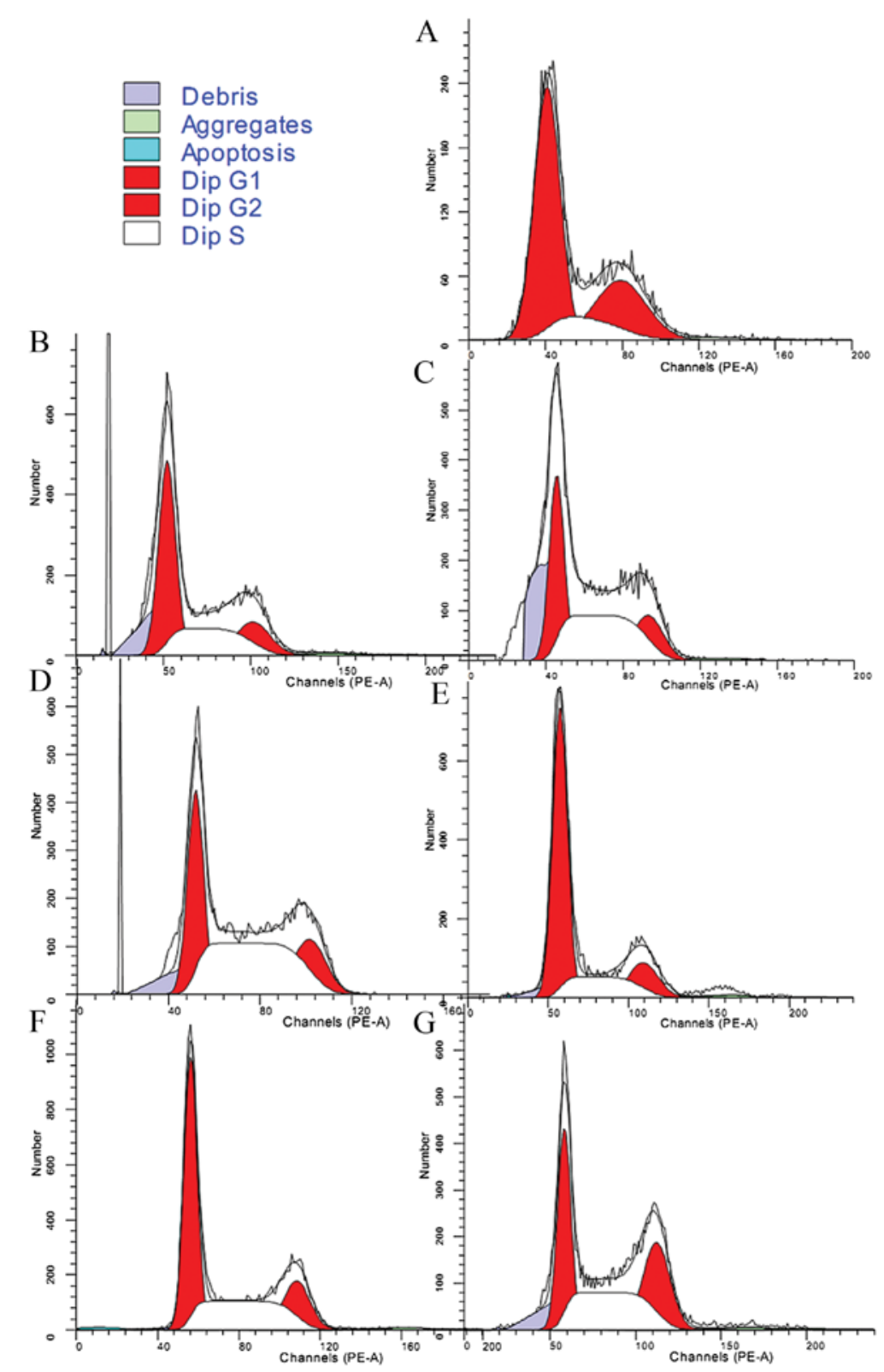

Figure 1. Effects of urotensin II (UII) at various concentrations on the cell cycle of NRK-52E cells. The cells were cultured for $48 \mathrm{~h}$ with various concentrations of UII $\left(10^{-10}, 10^{-9}, 10^{-8}\right.$, and $10^{-7} \mathrm{~mol} / 1$; Sigma-Aldrich). Nimodipine-pre-treated cells were incubated with $10^{-5} \mathrm{~mol} / 1$ nimodipine for 5 min then cultured with $10^{-8} \mathrm{~mol} / 1 \mathrm{UII}$ for $48 \mathrm{~h}$. EDTA-treated cells were treated with EDTA for $30 \mathrm{~min}$ and then cultured with $10^{-8} \mathrm{UII}$ for $48 \mathrm{~h}$. Finally $10^{-4} \mathrm{~mol} / 15$-bromodeoxyuridine (BrdU; Sigma-Aldrich) were added for the last $2 \mathrm{~h}$ before the cells and the supernatant were collected. Cells in the control group were cultured for $48 \mathrm{~h}$ without any treatment. Flow cytometry shows the distribution of the cells, analyzed using Modfit LT 3.0 software. (A) control; (B) $10^{-10} \mathrm{~mol} / 1 \mathrm{UII}$; (C) $10^{-9} \mathrm{~mol} / 1$ UII; (D) $10^{-8} \mathrm{~mol} / 1 \mathrm{UII}$; (E) $10^{-7} \mathrm{~mol} / 1 \mathrm{UII}$; (F) $10^{-8} \mathrm{~mol} / 1 \mathrm{UII}+\mathrm{EDTA}$; (G) $10^{-8} \mathrm{~mol} / 1 \mathrm{UII}+$ nimodipine. 

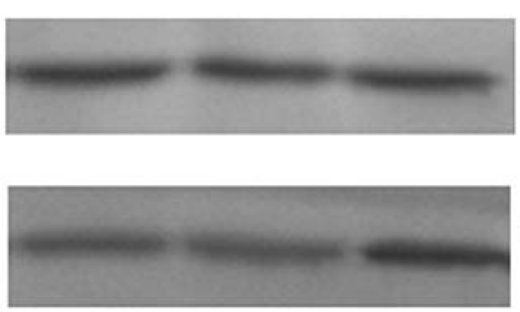
UII

BSA

AGE-BSA

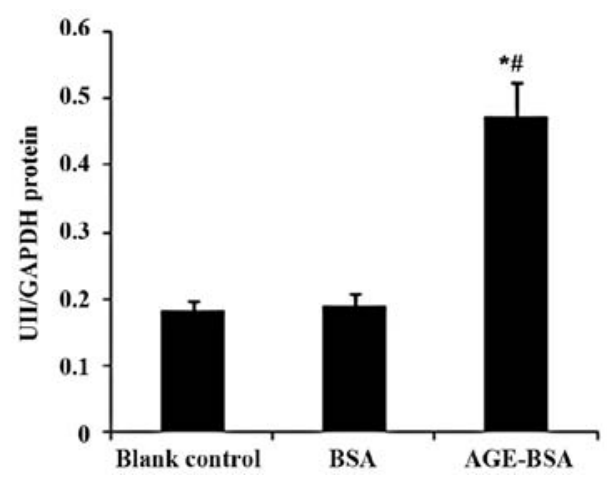

Figure 2. Advanced glycation end product (AGE)-bovine serum albumin (BSA) upregulates (urotensin II) UII protein expression in NRK-52E cells. Cells were cultured with AGE-BSA $(100 \mathrm{mg} / \mathrm{l}$ ) or BSA (control) and serum-free DMEM (blank control). Cells were collected at $48 \mathrm{~h}$ after treatment."P $<0.05$ vs. BSA control group; ${ }^{~} \mathrm{P}<0.05$ vs. blank group; $\mathrm{n}=6$ (cultured cells were seeded in a 6 -well culture plate; each group had 6 wells).

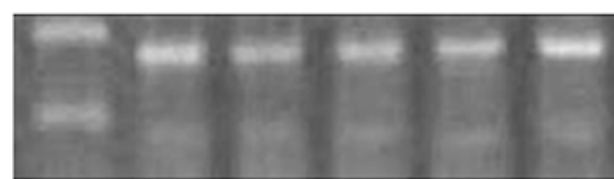

M

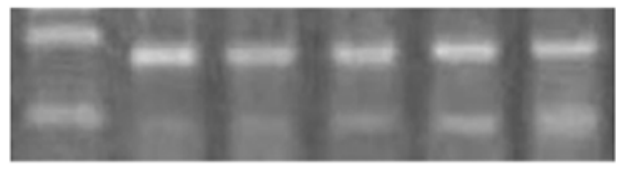

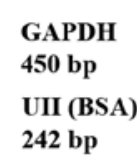

242 bp

GAPDH 450 bp

UII (AGE-BSA) 242 bp

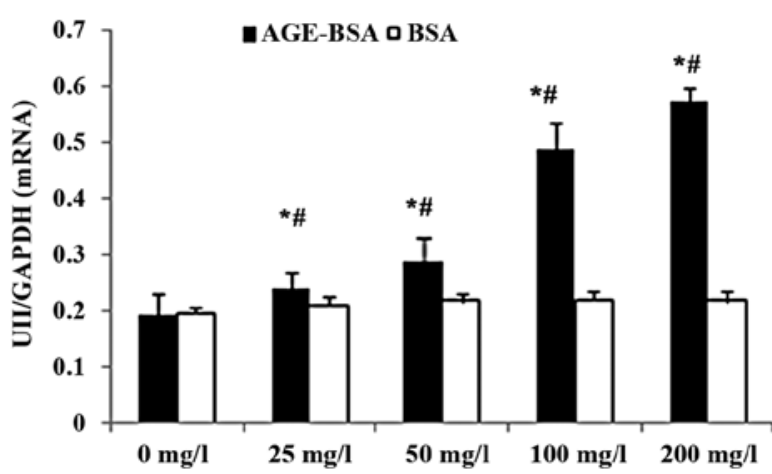

Figure 3. Advanced glycation end product (AGE)-bovine serum albumin (BSA) upregulates urotensin II (UII) mRNA expression in a concentration-dependent manner in NRK-52E cells. Cells were cultured with AGE-BSA at various concentrations $(0,25,50,100,200 \mathrm{mg} / \mathrm{l})$ or BSA (control). Cells were collected at $48 \mathrm{~h}$ after treatment. ${ }^{*} \mathrm{P}<0.05$ vs. corresponding BSA control group; ${ }^{*} \mathrm{P}<0.05$ vs. $0 \mathrm{mg} / \mathrm{l}$ group; $\mathrm{n}=6$ (cultured cells were seeded in a 6 -well culture plate; each group had 6 wells).
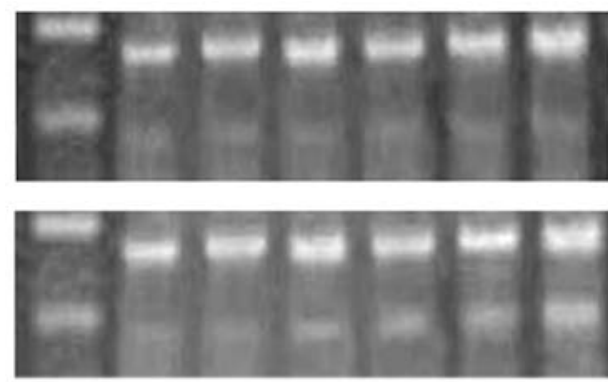

M

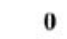

2

8

GAPDH
450 bp
UII (BSA)
242 bp
GAPDH
450 bp
UII (AGE-BSA)
242 bp
(h)

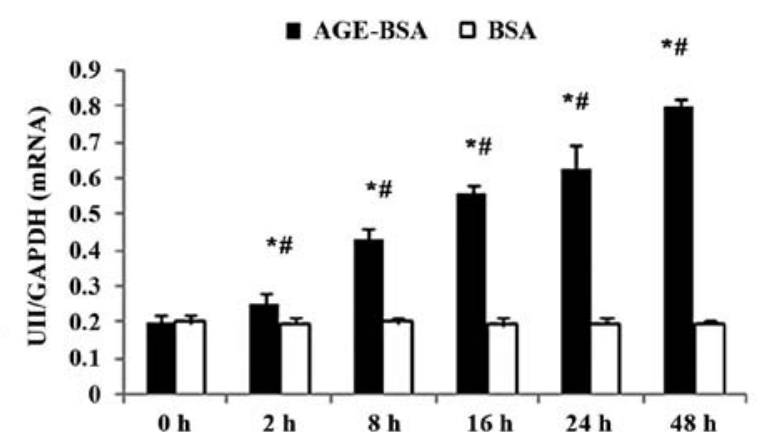

Figure 4. Advanced glycation end products (AGE)-bovine serum albumin (BSA) increases urotensin II (UII) mRNA expression in a time-dependent manner from $2 \mathrm{~h}$ to $48 \mathrm{~h}$ in NRK-52E cells. Cells were cultured with AGE-BSA at $100 \mathrm{mg} / 1$ or BSA (control). Cells were collected at $0,2,8,16,24$ or $48 \mathrm{~h}$ after treatment. ${ }^{*} \mathrm{P}<0.05$ vs. corresponding BSA control group; ${ }^{*} \mathrm{P}<0.05$ vs. 0 h group; $\mathrm{n}=6$ (cultured cells were seeded in a 6 -well culture plate; each group had 6 wells).

ment with AGE-BSA in a time- and concentration-dependent manner compared with the control (BSA-treated cells) (Fig. 5).

UII upregulates the mRNA expression and protein secretion of TGF- $\beta 1, F N$ and ColIV in NRK-52E cells. The NRK-52E cells treated with UII exhibited an increased protein and mRNA expression of TGF- $\beta 1$, as well as a concomitant upregulation of mRNA expression and protein secretion of FN and ColIV. Urantide attenuated these effects, while anti-TGF- $\beta 1$ antibody also inhibited the UII-stimulated secretion of FN and ColIV (Figs. 6-8).

\section{Discussion}

UII, a somatostatin-like vasoconstrictor peptide initially isolated from fish urophysis, has been identified in mammals, and in particular, in the nervous system, cardiovascular tissues and kidneys $(13,14)$. Studies showing that UII promotes cell proliferation and ECM accumulation (15-18) have been confirmed in airway and vascular smooth muscle cells, renal epithelial cells and renal carcinoma cell lines (19-24).

Early in vitro studies suggested that UII was an autocrine and paracrine growth factor for renal epithelial cells, 
$\mathbf{A}$

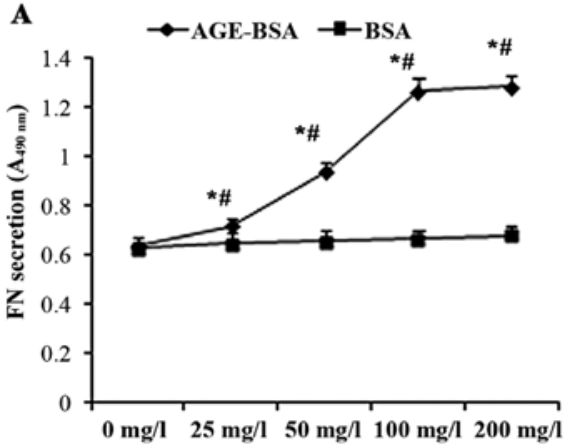

C

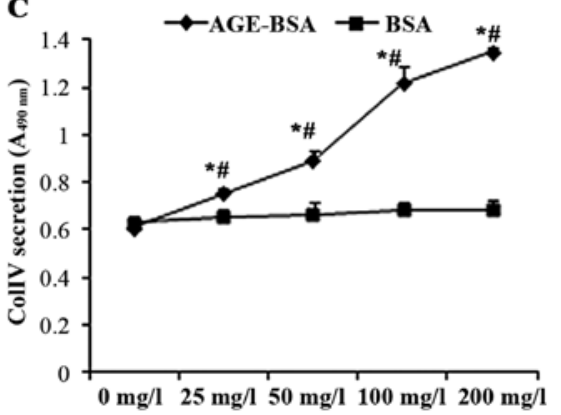

B

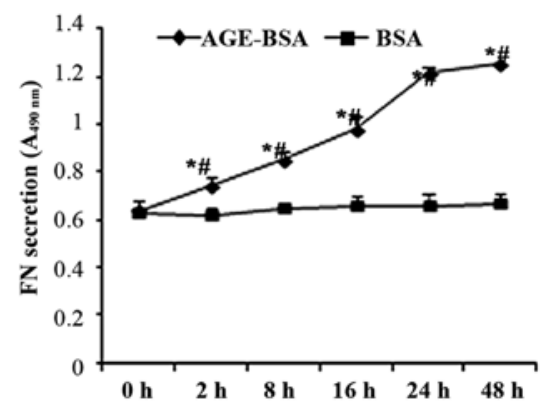

D

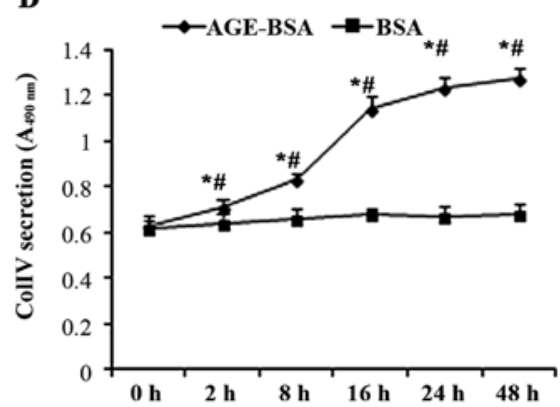

Figure 5. Advanced glycation end products (AGE)-bovine serum albumin (BSA) stimulates (A and B) fibronectin (FN) and (C and D) collagen IV (Col IV) protein secretion in a (A and C) concentration and (B and D) time-dependent manner in NRK-52E cells. Cells were cultured with AGE-BSA at various concentrations (0, $25,50,100,200 \mathrm{mg} / \mathrm{l}$ ) or BSA (control). Supernatants were collected at $48 \mathrm{~h}$ after treatment. Cells were cultured with AGE-BSA at $100 \mathrm{mg} / \mathrm{l}$ or BSA (control) Supernatants were collected at $0,2,8,16,24$ or $48 \mathrm{~h}$ after treatment. ${ }^{*} \mathrm{P}<0.05$ vs. corresponding BSA control group; ${ }^{*} \mathrm{P}<0.05 \mathrm{vs}$. $0 \mathrm{mg} / 1$ or $0 \mathrm{~h}$ group; $\mathrm{n}=6$ (cultured cells were seeded in a 6-well culture plate; each group had 6 wells).

$\mathbf{A}$
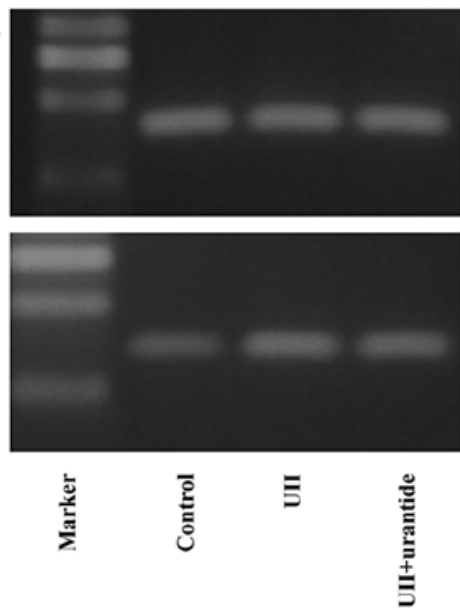

GAPDH GAP0 bp
bP

TGF- $\beta 1$
412 bp

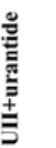

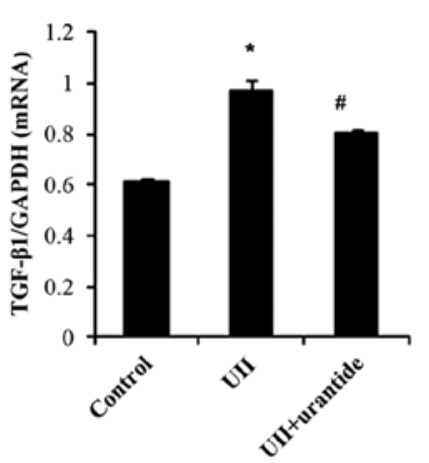

B

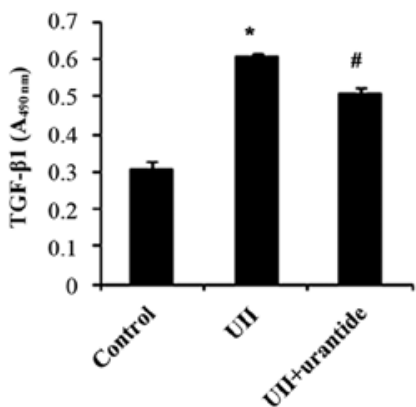

Figure 6. The urotensin II (UII) receptor antagonist, urantide, inhibits urotensin II (UII)-induced transforming growth factor (TGF)- $\beta 1$ (A) mRNA expression and (B) protein secretion in NRK-52E cells. Cells were cultured with $10^{-8} \mathrm{~mol} / \mathrm{l}$ urotensin II (UII) for $48 \mathrm{~h}$. UII receptor antagonist (urantide)-pre-treated cells were treated with urantide $\left(10^{-6} \mathrm{~mol} / \mathrm{l}\right.$; Shanghai Huada Tianyuan Biology Co., Ltd.) for $30 \mathrm{~min}$ and then cultured with $10^{-8} \mathrm{~mol} / 1 \mathrm{UII}$ for $48 \mathrm{~h}$. Cells in the control group were cultured for $48 \mathrm{~h}$ without any specific treatment. ${ }^{*} \mathrm{P}<0.05$ vs. control; ${ }^{*} \mathrm{P}<0.05$ vs. UII group; $\mathrm{n}=6$ (cultured cells were seeded in a 6 -well culture plate; each group had 6 wells).

acting via a mechanism encompassing the activation of both the protein kinase $\mathrm{C}$ (PKC) and extracellular signalregulated kinase (ERK)1/2 pathways, as well as $\mathrm{Ca}^{2+}$ influx via voltage-dependent $\mathrm{Ca}^{2+}$ channels (25). The present study demonstrated that UII increased the percentage of cells in the $\mathrm{S}$ phase in cultures of NRK-52E cells at concentrations between $10^{-10}-10^{-8} \mathrm{~mol} / \mathrm{l}$. This promoting effect on proliferation was not observed with UII at a concentration of $10^{-7} \mathrm{~mol} / \mathrm{l}$, possibly reflecting the saturation of UT. The attenuation of the promoting effect of UII on proliferation by nimodipine and EDTA, which reduce the influx of extracellular calcium, confirmed that this action is mediated by the influx of extracellular calcium ions.

It has been shown that the proximal renal tubule reabsorbs large quantities of AGEs when blood AGE concentrations are elevated. AGEs can potentially alter the structure and function of the kidneys, leading to increased glomerular hyperfiltration, basement membrane thickness, glomerulosclerosis and/or tubulointerstitial fibrosis in diabetes. Moreover, several in vivo and in vitro studies have implicated TGF- $\beta$ in AGE-induced renal damage in diabetes (26-28). EMC proteins, such as 

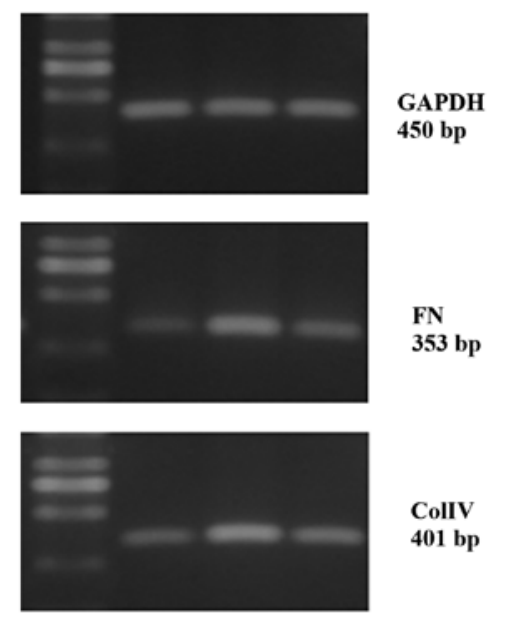

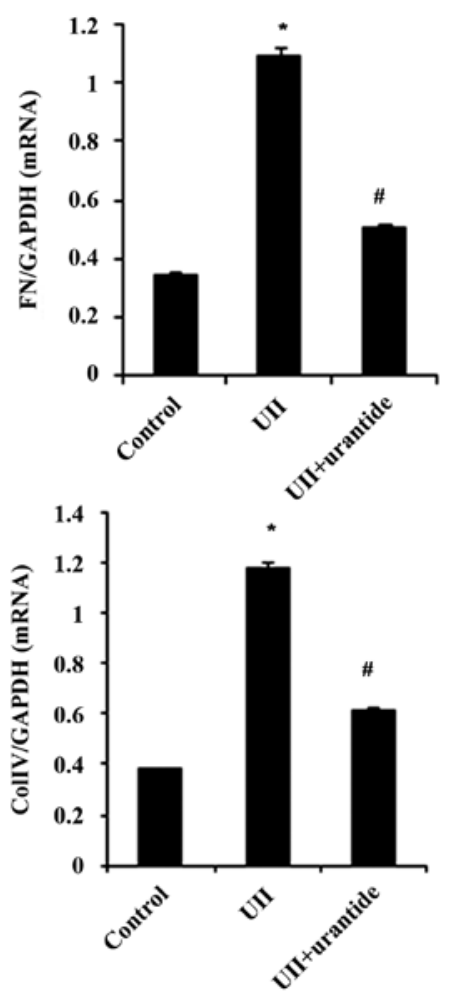

Figure 7. The urotensin II (UII) receptor antagonist, urantide, inhibits UII-induced fibronectin (FN) and collagen IV (Col IV) mRNA expression in NRK-52E cells Cells were cultured with $10^{-8} \mathrm{~mol} / 1 \mathrm{UII}$ for $48 \mathrm{~h}$. UII receptor antagonist (urantide)-pre-treated cells were treated with urantide (10 ${ }^{-6} \mathrm{~mol} / 1$; Shanghai Huada Tianyuan Biology Co., Ltd.) for $30 \mathrm{~min}$ and then cultured with $10^{-8} \mathrm{~mol} / 1$ UII for $48 \mathrm{~h}$. Cells in the control group were cultured for $48 \mathrm{~h}$ without any specific treatment. " $\mathrm{P}<0.05$ vs. control; ${ }^{"} \mathrm{P}<0.05$ vs. UII group; $\mathrm{n}=6$ (cultured cells were seeded in a 6 -well culture plate; each group had 6 wells).
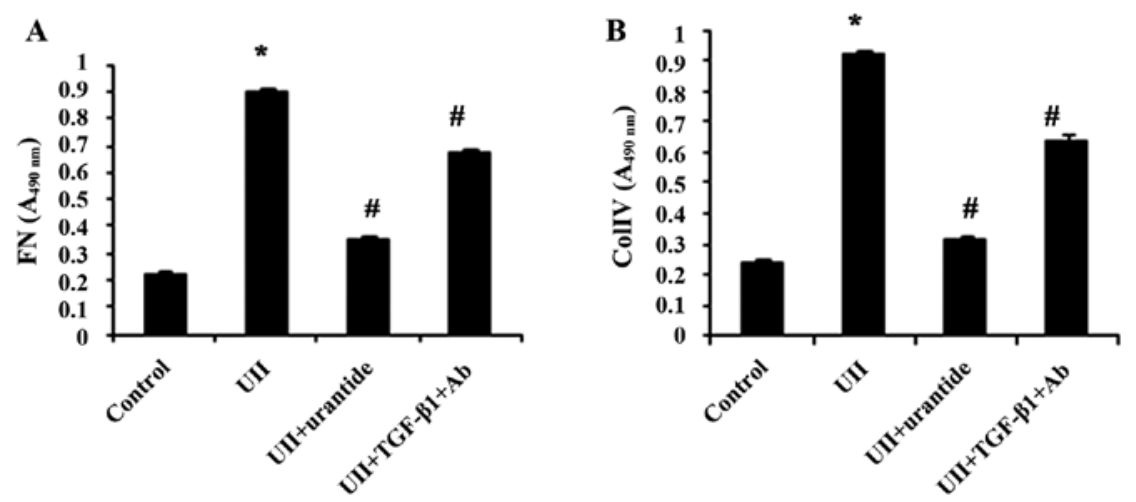

Figure 8. The urotensin II (UII) receptor antagonist, urantide, and a (transforming growth factor) TGF- $\beta$-specific neutralizing antibody inhibit UII-induced (A) fibronectin (FN) and (B) collagen IV (Col IV) secretion in NRK-52E cells. Cells were cultured with $10^{-8}$ mol/1 UII for 48 h. UII receptor antagonist (urantide)-pre-treated cells were treated with urantide $\left(10^{-6} \mathrm{~mol} / 1\right.$; Shanghai Huada Tianyuan Biology Co., Ltd.) for $30 \mathrm{~min}$ and then cultured with $10^{-8} \mathrm{~mol} / 1 \mathrm{UII}$ for $48 \mathrm{~h}$. Anti-TGF- $\beta 1$-pre-treated cells were treated with anti-TGF- $\beta 1$ antibody $\left(10 \mu \mathrm{g} / \mathrm{ml}\right.$; R\&D Systems Inc.) for 30 min and then cultured with $10^{-8} \mathrm{~mol} / 1 \mathrm{UII}$ for $48 \mathrm{~h}$. Cells in the control group were cultured for $48 \mathrm{~h}$ without any specific treatment. ${ }^{*} \mathrm{P}<0.05$ vs. control group; ${ }^{~} \mathrm{P}<0.05$ vs. UII group; $\mathrm{n}=6$ (cultured cells were seeded in a 6 -well culture plate; each group had 6 wells).

ColI, III, V and VII, and FN are normally distributed in the renal interstitium, while others such as laminin and ColIV are normally expressed in the basal membrane of the tubules. The expression of FN has been shown to be regulated by TGF- $\beta$, which is regarded as an early biomarker of fibrosis (29).

This study investigated the roles of UII in the AGE-induced overproduction of EMC in NRK-52E cells. UII has been shown to induce collagen synthesis and secretion through a mechanism involving the upregulation of TGF- $\beta 1$ expression and secretion in rat aortic vascular smooth muscle cells (30), implying that $\mathrm{TGF}-\beta 1 / \mathrm{Smad} 2 / 3$ signaling may mediate the effects of UII in vascular fibrosis. Previous data from our group demonstrated that the upregulation of TGF- $\beta 1$ expression by UII and GPR14-targeted RNA interference decreased the UII-induced upregulation of TGF- $\beta 1$ (31). The present study found that in NRK-52E cells, the inhibition of UII function attenuated the increases in TGF- $\beta 1, \mathrm{FN}$, and ColIV mRNA expression, and that an anti-TGF- $\beta 1$ antibody attenuated the UII-induced increase in FN and ColIV protein secretion. At the same time, AGEs increased the protein and mRNA expression of UII, and increased the protein secretion of FN and ColIV. 
The findings of this study suggested that the AGE-induced upregulation of UII plays an important role in TGF- $\beta 1$-mediated EMC synthesis, most likely through autocrine and/or paracrine mechanisms, and implicated the UII-TGF- $\beta 1$ signaling pathway in renal fibrosis. It can be reasonably speculated that such a mechanism contributes to tubulointerstitial nephropathy in diabetes patients. That said, it remains unclear as to whether renal fibrosis is caused by the hyperglycemia-induced overproduction of EMC components, or whether TGF- $\beta 1$ is involved in the UII-induced phenotypic differentiation of renal tubular epithelial cells into myofibroblasts. Further studies are warranted in order to elucidate the underlying mechanisms.

\section{Acknowledgements}

This study was supported by the Scientific Research of Heilongjiang Province Health Department (grant no. 2013008 to Lin Tian) and the Postdoctoral Scientific Research Developmental Fund of Heilongjiang Province (grant no. LBH-Q14121 to Lin Tian).

\section{References}

1. You Z, Al Kindi H, Abdul-Karim A, Barrette PO and Schwertani A: Blocking the urotensin II receptor pathway ameliorates the metabolic syndrome and improves cardiac function in obese mice. FASEB J 28: 1210-1220, 2014.

2. Vaudry H, Leprince J, Chatenet D, Fournier A, Lambert DG, Le Mével JC, Ohlstein EH, Schwertani A, Tostivint H and Vaudry D: International Union of Basic and Clinical Pharmacology. XCII. Urotensin II, urotensin II-related peptide, and their receptor: from structure to function. Pharmacol Rev 67: 214-258, 2015.

3. Forbes JM, Cooper ME, Oldfield MD and Thomas MC: Role of advanced glycation end products in diabetic nephropathy. J Am Soc Nephrol 14 (Suppl 3): S254-S258, 2003.

4. Yamagishi S: Role of advanced glycation end products (AGEs) and receptor for AGEs (RAGE) in vascular damage in diabetes. Exp Gerontol 46: 217-224, 2011.

5. Shenouda A, Douglas SA, Ohlstein EH and Giaid A: Localization of urotensin-II immunoreactivity in normal human kidneys and renal carcinoma. J Histochem Cytochem 50: 885-889, 2002.

6. Hsu YH, Chen TH, Chen YC, Cheng CY, Sue YM, Chen JR and Chen $\mathrm{CH}$ : Urotensin II exerts antiapoptotic effect on NRK-52E cells through prostacyclin-mediated peroxisome proliferator-activated receptor alpha and Akt activation. Mol Cell Endocrinol 381: 168-174, 2013.

7. Totsune K, Takahashi K, Arihara Z, Sone M, Ito S and Murakami O: Increased plasma urotensin II levels in patients with diabetes mellitus. Clin Sci (Lond) 104: 1-5, 2003.

8. Xie $\mathrm{N}$ and Liu L: Elevated expression of urotensin II and its receptor in great artery of type 2 diabetes and its significance. Biomed Pharmacother 63: 734-741, 2009.

9. Langham RG, Kelly DJ, Gow RM, Zhang Y, Dowling JK, Thomson NM and Gilbert RE: Increased expression of urotensin II and urotensin II receptor in human diabetic nephropathy. Am J Kidney Dis 44: 826-831, 2004.

10. Lam S, van der Geest RN, Verhagen NA, Daha MR and van Kooten C: Secretion of collagen type IV by human renal fibroblasts is increased by high glucose via a TGF-beta-independent pathway. Nephrol Dial Transplant 19: 1694-1701, 2004.

11. Park JT, Kato M, Lanting L, Castro N, Nam BY, Wang M, Kang SW and Natarajan R: Repression of let-7 by transforming growth factor- $\beta 1$-induced Lin 28 upregulates collagen expression in glomerular mesangial cells under diabetic conditions. Am J Physiol Renal Physiol 307: F1390-F1403, 2014.

12. Dai HY, Kang WQ, Wang X, Yu XJ, Li ZH, Tang MX, Xu DL, Li CW, Zhang Y and Ge ZM: The involvement of transforming growth factor-betal secretion in urotensin II-induced collagen synthesis in neonatal cardiac fibroblasts. Regul Pept 140: 88-93, 2007.
13. Coulouarn Y, Lihrmann I, Jegou S, Anouar Y, Tostivint H, Beauvillain JC, Conlon JM, Bern HA and Vaudry H: Cloning of the cDNA encoding the urotensin II precursor in frog and human reveals intense expression of the urotensin II gene in motoneurons of the spinal cord. Proc Natl Acad Sci USA 95: 15803-15808, 1998.

14. Ames RS, Sarau HM, Chambers JK, Willette RN, Aiyar NV, Romanic AM, Louden CS, Foley JJ, Sauermelch CF, Coatney RW, et al: Human urotensin-II is a potent vasoconstrictor and agonist for the orphan receptor GPR14. Nature 401: 282-286, 1999.

15. Matsushita M, Shichiri M, Imai T, Iwashina M, Tanaka H, Takasu N and Hirata Y: Co-expression of urotensin II and its receptor (GPR14) in human cardiovascular and renal tissues. J Hypertens 19: 2185-2190, 2001.

16. Zhang YG, Li YG, Liu BG, Wei RH, Wang DM, Tan XR, Bu DF, Pang YZ and Tang CS: Urotensin II accelerates cardiac fibrosis and hypertrophy of rats induced by isoproterenol. Acta Pharmacol Sin 28: 36-43, 2007.

17. Guidolin D, Albertin G, Oselladore B, Sorato E, Rebuffat P, Mascarin A and Ribatti D: The pro-angiogenic activity of urotensin-II on human vascular endothelial cells involves ERK1/2 and PI3K signaling pathways. Regul Pept 162: 26-32, 2010.

18. Albertin G, Guidolin D, Sorato E, Oselladore B, Tortorella C and Ribatti D: Urotensin-II-stimulated expression of pro-angiogenic factors in human vascular endothelial cells. Regul Pept 172: 16-22, 2011.

19. Sauzeau V, Le Mellionnec E, Bertoglio J, Scalbert E, Pacaud P and Loirand G: Human urotensin II-induced contraction and arterial smooth muscle cell proliferation are mediated by RhoA and Rho-kinase. Circ Res 88: 1102-1104, 2001.

20. Watanabe T, Pakala R, Katagiri T and Benedict CR: Synergistic effect of urotensin II with serotonin on vascular smooth muscle cell proliferation. J Hypertens 19: 2191-2196, 2001.

21. Matsushita M, Shichiri M, Fukai N, Ozawa N, Yoshimoto T, Takasu $\mathrm{N}$ and Hirata Y: Urotensin II is an autocrine/paracrine growth factor for the porcine renal epithelial cell line, LLCPK1. Endocrinology 144: 1825-1831, 2003.

22. Takahashi K, Totsune K, Murakami O, Arihara Z, Noshiro T, Hayashi Y and Shibahara S: Expression of urotensin II and its receptor in adrenal tumors and stimulation of proliferation of cultured tumor cells by urotensin II. Peptides 24: 301-306, 2003.

23. Dai HY, He T, Li XL, Xu WL and Ge ZM: Urotensin-2 promotes collagen synthesis via ERK1/2-dependent and ERK1/2independent TGF- $\beta 1$ in neonatal cardiac fibroblasts. Cell Biol Int 35: 93-98, 2011.

24. Xu S, Wen H and Jiang H: Urotensin II promotes the proliferation of endothelial progenitor cells through p38 and p44/42 MAPK activation. Mol Med Rep 6: 197-200, 2012.

25. Adebiyi A: Rgs2 regulates urotensin II-induced intracellular $\mathrm{Ca}^{2+}$ elevation and contraction in glomerular mesangial cells. J Cell Physiol 229: 502-511, 2014.

26. Fukami K, Ueda S, Yamagishi S, Kato S, Inagaki Y, Takeuchi M, Motomiya Y, Bucala R, Iida S, Tamaki K, et al: AGEs activate mesangial TGF-beta-Smad signaling via an angiotensin II type I receptor interaction. Kidney Int 66: 2137-2147, 2004.

27. Yamagishi S, Fukami K, Ueda S and Okuda S: Molecular mechanisms of diabetic nephropathy and its therapeutic intervention. Curr Drug Targets 8: 952-959, 2007.

28. Ishibashi Y, Matsui T, Takeuchi M and Yamagishi S: Metformin inhibits advanced glycation end products (AGEs)-induced renal tubular cell injury by suppressing reactive oxygen species generation via reducing receptor for AGEs (RAGE) expression. Horm Metab Res 44: 891-895, 2012.

29. Eismann U, Sommer M, Kosmehl H, Appenroth D, Fleck C and Stein G: Fibronectin splice variants-prognostic markers for the stage of renal interstitial fibrosis in the rat. Nephron 92: 379-388, 2002.

30. Zhao J, Ding W, Song N, Dong X, Di B, Peng F and Tang C: Urotensin II-induced collagen synthesis in cultured smooth muscle cells from rat aortic media and a possible involvement of transforming growth factor- $\beta 1 / \mathrm{Smad} 2 / 3$ signaling pathway. Regul Pept 182: 53-58, 2013.

31. Tian L, Li C, Qi J, Fu P, Yu X, Li X and Cai L: Diabetes-induced upregulation of urotensin II and its receptor plays an important role in TGF-beta1-mediated renal fibrosis and dysfunction. Am J Physiol Endocrinol Metab 295: E1234-E1242, 2008. 